\title{
Autosomal recessive centronuclear myopathy
}

INSERM

\section{Source}

INSERM. (1999). Orphanet: an online rare disease and orphan drug data base. Autosomal recessive centronuclear myopathy. ORPHA:169186

Autosomal recessive centronuclear myopathy (AR-CNM) is an inherited neuromuscular disorder defined by numerous centrally placed nuclei on muscle biopsy and clinical features of a congenital myopathy. 